\title{
Pengembangan $e$-Worksheets Berorientasi ICT Literacy Pada Mata Kuliah Pengantar Teknologi Informasi Pendidikan Matematika Untuk Mahasiswa Tahun Pertama
}

\author{
Metta Liana ${ }^{1}$, Okta Alpindo ${ }^{2}$ \\ ${ }^{1,2}$ Fakultas Keguruan dan Ilmu Pendidikan, Universitas Maritim Raja Ali Haji \\ Jl. Politeknik Senggarang, Kota Tanjungpinang, Indonesia \\ mettaliana@umrah.ac.id
}

\begin{abstract}
In the era of the industrial revolution 4.0, the young generation is required to be proficient in using technology in living life. One of the efforts made is to have good technological literacy in order to control this technology. The provision of teaching materials in the form of e-Worksheets oriented to ICT literacy facilitates students to be more responsible for their own learning experiences. The E-Worksheets were developed using the Research and Development (R\&D) method until the 7th stage. The research respondents consisted of 4 expert lecturers and 30 students of the mathematics education study program. The results of the feasibility test of e-Worksheets obtained a percentage of $76.56 \%$ with the appropriate category for use in learning. While the results of student responses related to the use of e-Worksheets obtained a score of $83.6 \%$ with the category of strongly agreeing to use e-Worksheets in learning. Thus, these e-Worksheets can be used by first-year students in an introductory course on mathematics education information technology that can practice ICT literacy.
\end{abstract}

Keywords: e-Worksheets, ICT literacy, Technology literacy

\begin{abstract}
Abstrak
Di era revolusi industri 4.0 generasi muda dituntut untuk mahir dalam menggunakan teknologi dalam menjalani kehidupan. Salah satu upaya yang dilakukan adalah dengan memiliki literasi teknologi yang baik agar bisa mengontrol teknologi tersebut. Penyediaan bahan ajar dalam bentuk e-Worksheets yang berorientasi ICT literacy memfasilitasi mahasiswa untuk lebih bertanggung jawab atas pengalaman belajar mereka sendiri. E-Worksheets yang dikembangkan dengan metode Research and Development $(R \& D)$ sampai pada tahap ke-7. Responden penelitian ini terdiri dari 4 orang dosen ahli dan 30 orang mahasiswa program studi pendidikan matematika. Hasil uji kelayakan $e$-Worksheets diperoleh persentase sebesar 76.56\% dengan kategori layak untuk digunakan dalam pembelajaran. Sedangkan hasil respon mahasiswa terkait penggunaan $e$-Worksheets diperoleh skor $83.6 \%$ dengan kategori sangat setuju untuk menggunakan $e$-Worksheets dalam pembelajaran. Dengan demikian, $e$ Worksheets ini sudah bisa digunakan oleh mahasiswa tahun pertama pada mata kuliah pengantar teknologi informasi pendidikan matematika yang bisa melatihkan ICT literacy.
\end{abstract}

Kata kunci: e-Worksheets, ICT literacy, Literasi teknologi

Copyright (c) 2021 Metta Liana, Okta Alpindo

$\triangle$ Corresponding author: Metta Liana

Email Address: mettaliana@umrah.ac.id (J1. Politeknik Senggarang, Kota Tanjungpinang, Indonesia)

Received 10 Januari 2021, Accepted 13 Februari 2021, Published 24 Februari 2021

\section{PENDAHULUAN}

Di masa lalu, industri dipengaruhi oleh perubahan dan inovasi teknologi. Paradigma ini disebut revolusi industri. Saat ini, seiring dengan perkembangan digitalisasi dan robotik, generasi muda sedang menghadapi revolusi industri berikutnya yang dikenal dengan revolusi industri 4.0. Revolusi industri 4.0 memanfaatkan teknologi komunikasi dan penemuan-penemuan inovatif dalam mendorong perkembangan industri manufaktur (Kagermann, Wahlster, \& Helbig, 2013). Seiring hadirnya revolusi industri 4.0 beberapa profesi nantinya akan tergantikan, teknologi yang muncul memiliki pengaruh besar pada pendidikan setiap orang. Hanya pribadi yang berkualitas dan berpendidikan 
tinggi yang dapat mengontrol teknologi tersebut. Setiap generasi muda harus mempersiapkan dirinya dalam menghadapi tantangan era 4.0, salah satunya dengan pemahaman literasi teknologi yang baik.

Selain itu, digitalisasi dianggap sebagai megatrend global yang merembes ke semua lapisan masyarakat. Efeknya terwujud dalam aktivitas sehari-hari seperti belanja, transaksi perbankan, cara berkomunikasi, mendengarkan musik, menonton tv dan bermain game. Serta pergantian digital pasti juga mempengaruhi berbagai praktik dan kebijakan pendidikan. Dengan digitalisasi, peserta didik memiliki akses ilmu yang bervariasi dan kedalaman informasi yang lebih luas sehingga tidak selalu bergantung ke pendidik (guru/dosen). Pendidik tidak lagi harus jadi penentu semua kegiatan di kelas tetapi dapat menjadi fasilitator yang berperan dalam membantu, mendorong, mempertanyakan dan memberi tantangan ke peserta didik terkait materi yang dipelajari. Peserta didik lebih banyak memegang kendali dan bertanggung jawab untuk pembelajaran mereka sendiri (Wildemeersch \& Jütte, 2018).

Seringkali muncul anggapan bahwa setiap anak paham/terampil dengan teknologi karena mereka terpapar teknologi sejak dini, hal tersebut kuranglah tepat. Setiap anak terampil dengan teknologi hanya ketika mereka menyadari fungsinya, memiliki akses ke teknologi dan berlatih dalam menggunakannya. Setiap anak di masa sekarang ini tidak lebih atau mampu belajar menggunakan teknologi yang tersedia daripada anak di masa lalu. Faktanya, setiap anak di masa sekarang biasanya menggunakan teknologi terutama untuk kegiatan sosial (yaitu, komunikasi dan hiburan) tetapi tidak harus untuk pembelajaran akademis (Peck, C., Cuban, L., \& Kirkpatrick, 2003).

Membangun pengetahuan adalah aktivitas manusia yang dapat difasilitasi oleh teknologi, menyadari hal tersebut peserta didik harus bergeser dalam melihat teknologi sebagai item yang memotivasi atau menghibur saja dengan mulai melihat teknologi sebagai alat untuk menyelesaikan tujuan pembelajaran tertentu. Peserta didik pada umumnya antusias menggunakan teknologi pendidikan, namun pendidik terkadang salah mengira minat teknologi untuk literasi teknologi, dan aktivitas yang melibatkan teknologi untuk pembelajaran melalui teknologi. Dengan kata lain, motivasi untuk menggunakan teknologi saja tidak cukup, peserta didik harus melewati kebaruan teknologi dan mulai menggunakannya karena mereka melihat bagaimana penggunaan teknologi dapat memfasilitasi pembelajaran mereka. Ketika mereka mendapatkan perspektif ini, teknologi menjadi transparan, dan efektif dalam proses pembelajaran (Davies, Sprague, \& New, 2008).

Literasi teknologi didefinisikan sebagai kemampuan individu dalam mengadopsi, mengadaptasi, menemukan dan mengevaluasi teknologi untuk hal positif dalam kehidupannya (Hansen, 2003). Selain itu, tiap pribadi yang melek teknologi dapat menggunakan teknologi sebagai alat untuk berorganisasi, berkomunikasi, meneliti dan memecahan masalah (Eisenberg, M.B., \& Johnson, 2002). Dalam penelitian ini, literasi teknologi dalam dunia pendidikan didefinisikan sebagai kemampuan untuk menggunakan teknologi secara efektif (baik itu alat, peralatan atau perangkat apapun baik elektronik atau mekanis) untuk menyelesaikan tugas-tugas pembelajaran yang diperlukan oleh mahasiswa pendidikan matematika. Setiap pribadi yang melek teknologi tahu apa yang mampu 
dilakukan oleh teknologi, mereka dapat menggunakan teknologi dengan mahir, dan mereka membuat keputusan yang cerdas tentang teknologi mana yang akan digunakan dan kapan menggunakannya.

Teknologi informasi dan komunikasi (TIK) telah menyebar dalam masyarakat modern sebagai alat untuk mengubah sistem pendidikan, mendukung pembangunan ekonomi melalui penciptaan produk dan layanan baru, menyediakan akses ke informasi dan keahlian untuk mendukung peningkatan di bidang pertanian, kesehatan dan pendidikan, serta menghubungkan komunitas, pendidik, dan peserta didik. TIK memberi pendidik dan peserta didik sumber daya untuk mengumpulkan dan menganalisis data, membuat presentasi multimedia, dan memperoleh pengetahuan yang lebih mendalam (Australian Council for Educational Research, 2016).

Namun, salah satu syarat untuk menggunakan potensi TIK adalah memiliki akses ke teknologi dan internet, dan terbukti bahwa terdapat disparitas yang luas sejauh mana teknologi tersebut tersedia bagi masyarakat, baik antar maupun di dalam negara (Anderson \& Ainley, 2010). Kondisi kedua untuk menggunakan berbagai macam prospek yang ditawarkan oleh TIK adalah pengembangan keahlian untuk menggunakan TIK dengan cara yang efektif. Kemampuan yang dibutuhkan ini yang dikenal dengan ICT literacy.

ICT literacy didefinisikan sebagai kemampuan dalam menggunakan teknologi digital, alat komunikasi, dan/atau jaringan untuk mengakses, mengelola, mengintegrasikan, mengevaluasi, dan menciptakan informasi agar dapat berfungsi dalam membangun masyarakat yang berpengetahuan (Gaston, Station, \& Taylor, 2002). Jika ICT literacy/ literasi TIK ingin memiliki efek transformatif pada kehidupan masyarakat, hal ini harus dipahami sebagai seperangkat alat secara luas yang dapat diintegrasikan di berbagai konteks kehidupan. Tugas yang dilakukan di sekolah, di tempat kerja, dan dalam kehidupan sehari-hari semakin membutuhkan pemahaman dan penerapan integrasi keterampilan kognitif, literasi, dan teknologi ini.

ICT literacy dapat dicapai dengan baik melalui pengalaman yang mengintegrasikan pembelajaran kognitif dan teknis. Apabila kurikulum fokus tunggal dan berdiri sendiri maka antara capaian akademik atau teknis akan membatasi pencapaian ICT literacy peserta didik. Keterampilan ICT literacy perlu diintegrasikan secara tepat ke dalam kurikulum yang membahas keterampilan kognitif serta keterampilan yang menangani TI dan teknis untuk memastikan peningkatan ICT literacy (Gaston et al., 2002).

Kedepannya dalam menghadapi dunia kerja, tiap perusahaan akan menggunakan teknologi baru dan media pintar. Tidak menutup kemungkinan sistem pendidikan 3.0 menjadi pendidikan 4.0. Pendidikan 4.0 akan menggabungkan dunia nyata dan virtual informasi (Beneova \& Tupa, 2017). Sumber daya virtual seperti kacamata untuk virtual reality yang akan digunakan dalam mengajar. Mutu pendidikan tinggi akan terus ditingkatkan. Dari paparan di atas maka perlunya Mata Kuliah Pengantar Teknologi Informasi pada program studi pendidikan matematika untuk menghadapi tantangan revolusi industri 4.0 di era abad 21 ini. Tantangan revolusi industri 4.0 dalam dunia pendidikan salah satunya adalah bagaimana membekali peserta didik dalam memahami literasi 
teknologi. Untuk memfasilitasi peserta didik maka diperlukan bahan ajar yang menunjang pembelajaran, bahan ajar disini disajikan dalam bentuk e-Worksheets. Dimana bahan ajar $e$ Worksheets ini diartikan sebagai lembar yang berisi tugas-tugas yang harus dikerjakan peserta didik (Departemen Pendidikan Nasional, 2008). Tiap-tiap e-Worksheets ini terdiri dari komponen judul; petunjuk belajar; kompetensi dasar; informasi pendukung; tugas dan penilaian. Setiap instruksi dan tugas yang ada pada e-Worksheets akan membuat peserta didik membangun pengetahuan, mengembangkan pemikiran, dan melatih skill (Asrizal, Amran, Ananda, \& Festiyed, 2019). Penggunaan istilah $e$-Worksheets dikarenakan bahan ajar ini tersedia dalam format electronic (soft file berupa pdf). Hal ini ditujukan untuk memfasilitasi peserta didik yang belajar secara daring ataupun luring. Pengembangan bahan ajar e-Worksheets ini dirancang berorientasi pada ICT literacy.

\section{METODE}

Pengembangan e-Worksheets ini menggunakan konsep Research and Development (Borg, W. R., $\&$ Gall, 2003). Pengembangan ini hanya sampai pada tahap 7 yaitu revisi produk operasional. Pada Gambar 1. berikut disajikan road map penelitian R\&D yang digunakan:

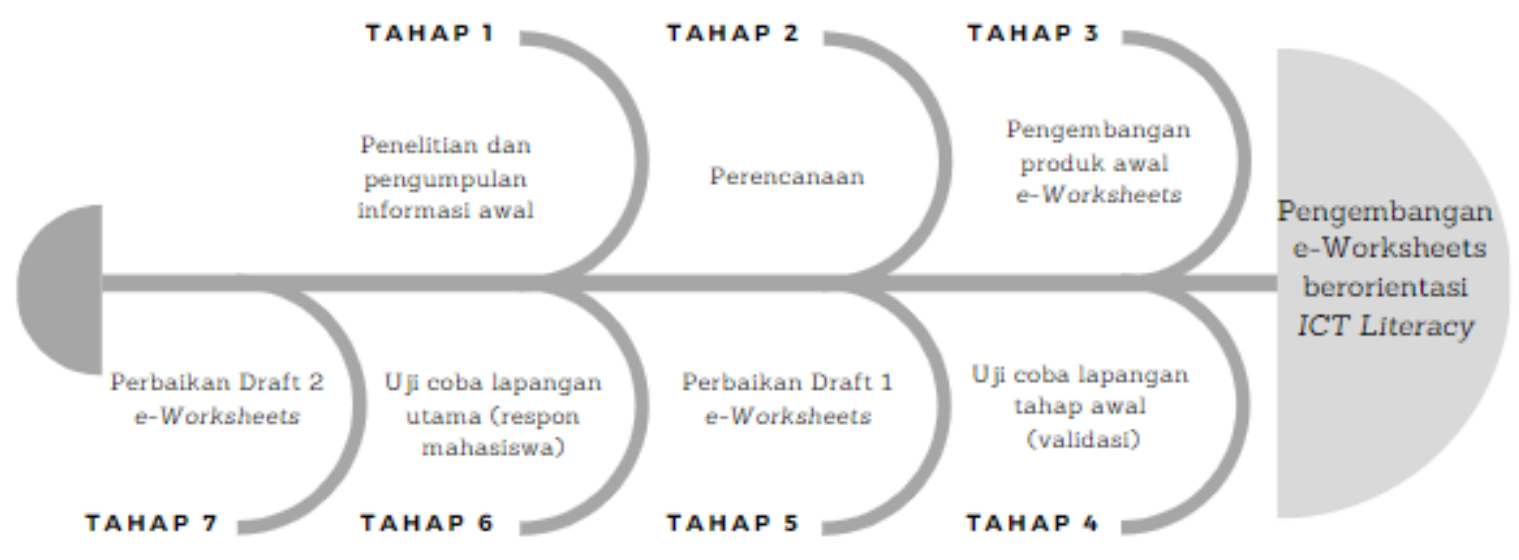

Gambar 1. Road Map Penelitian R\&D yang dikembangkan

Selain itu, subjek yang terlibat dalam penelitian ini adalah mahasiswa tahun pertama pada Program Studi Pendidikan Matematika, Fakultas Keguruan dan Ilmu Pendidikan (FKIP) di salah satu universitas di Kepulauan Riau, sedangkan partisipan yang terlibat adalah dosen yang berkompetensi dibidangnya untuk validasi $e$-Worksheets ini. Ada dua instrumen penelitian yang digunakan yaitu instrumen kelayakan e-Worksheets berorientasi ICT literacy dan instrumen angket persepsi mahasiswa terhadap $e$-Worksheets. Instrumen kelayakan ini terbagi dua, yaitu instrumen penilaian kualitas isi $e$-Worksheets dalam bentuk angket yang berupa rating scale dan saran secara kualitatif dari dosen/ahli untuk segi konten maupun materi ajar dan kaidah-kaidah evaluasi melalui judgement untuk keperluan pertimbangan revisi $e$-Worksheets yang berisi 18 aspek penilaian yang meliputi kesesuaian antara uraian materi dengan kompetensi dasar, kesesuaian antara pemaparan dan penulisan konten, kesesuaian kegiatan mahasiswa dengan pencapaian ICT literacy. Data hasil penilaian kualitas isi $e$-Worksheets diolah menggunakan rating scale dengan persamaan 


$$
P=\frac{f}{n}
$$

dimana:

$\mathrm{P}=$ Persentase skor akhir

$\mathrm{f}=$ jumlah skor yang diperoleh

$\mathrm{N}=$ jumlah skor total

Hasil persentase skor yang diperoleh dianalisis dan diinterpretasikan merujuk pada Tabel 1.

Tabel 1. Kriteria Kualitas isi e-Worksheets

\begin{tabular}{|c|c|}
\hline Persentase penilaian & Kriteria Kualitas \\
\hline $0 \%<x \leq 25 \%$ & Sangat kurang sesuai \\
\hline $25 \%<x \leq 50 \%$ & Kurang sesuai \\
\hline $50 \%<x \leq 75 \%$ & Sesuai \\
\hline $75 \%<x \leq 100 \%$ & Sangat sesuai \\
\hline
\end{tabular}

(Sumber: Sugiyono, 2019)

Instrumen kelayakan berikutnya yaitu instrumen keterpahaman ide pokok wacana yang dilakukan oleh mahasiswa yang berisi 4 langkah, yaitu: menentukan ide pokok atau pikiran utama dari wacana tersebut; menuliskan keterangan-keterangan dari wacana tersebut yang mendukung pikiran utama; melingkari kata-kata pada wacana tersebut yang belum dikenali atau tidak dimengerti artinya; menggarisbawahi kalimat-kalimat pada wacana tersebut yang sulit dipahami (Sinaga, Suhandi, \& Liliasari, 2014). Analisis keterpahaman ide pokok dilakukan dengan pemberian skor, skor tertinggi jika mengandung seluruh atau sebagian besar kata kunci yang ditetapkan peneliti. Sebaliknya, skor terendah diberikan jika jawaban mahasiswa tidak mengandung kata kunci tersebut. Persentase jawaban ide pokok mahasiswa dihitung dan diinterpretasikan dalam kategori keterpahaman ide pokok pada Tabel 2.

Tabel 2. Kriteria Keterpahaman Ide pokok e-Worksheets

\begin{tabular}{|c|c|}
\hline Persentase keterpahaman & Kriteria keterpahaman \\
\hline $0 \%<x \leq 40 \%$ & Rendah (kategori sulit) \\
\hline $40 \%<x \leq 60 \%$ & Sedang (kategori instruksional) \\
\hline$x>60 \%$ & Tinggi (kategori mandiri) \\
\hline
\end{tabular}

(Sumber: Rankin, et al, 1969)

Berdasarkan data uji kualitas dan uji keterpahaman ide pokok terhadap e-Worksheets yang dikembangkan kemudian dirata-ratakan sehingga nantinya diperoleh kategori kelayakan $e$-Worksheets tersebut. Analisis deskriptif data tersebut dikelompokkan sesuai kategori pada Tabel 3.

Tabel 3. Kriteria Kelayakan e-Worksheets

\begin{tabular}{|c|c|}
\hline Persentase kelayakan & Kriteria Kelayakan \\
\hline$x \leq 60 \%$ & Kurang layak \\
\hline $60 \%<x \leq 75 \%$ & Cukup layak \\
\hline $75 \%<x \leq 90 \%$ & Layak \\
\hline $90 \%<x \leq 100 \%$ & Sangat layak \\
\hline
\end{tabular}

(Sumber: Sudjana, 2005)

Selanjutnya, selain instrumen kelayakan $e$-Worksheets digunakan instrumen penilaian persepsi mahasiswa terkait persetujuan penggunaan e-Worksheets dihitung menggunakan persamaan 


$$
P=\frac{x_{i}}{x_{m a k}}
$$

dimana:

$P=$ Persentase skor yang diperoleh

$x_{i}=$ jumlah skor yang diperoleh tiap item

$x_{\max }=$ jumlah skor ideal untuk seluruh item

Hasil perhitungan angket persepsi mahasiswa diinterpretasikan merujuk pada Tabel 4.

Tabel 4. Kriteria Persepsi Mahasiswa terkait e-Worksheets

\begin{tabular}{|c|c|}
\hline Persentase Persepsi & Kriteria Persepsi \\
\hline $0 \%<x \leq 25 \%$ & Sangat tidak setuju \\
\hline $25 \%<x \leq 50 \%$ & Kurang setuju \\
\hline $50 \%<x \leq 75 \%$ & Setuju \\
\hline $75 \%<x \leq 100 \%$ & Sangat setuju \\
\hline
\end{tabular}

(Sumber: Sugiyono, 2011)

\section{HASIL DAN DISKUSI}

Hasil pengembangan $e$-Worksheets berorientasi ICT literacy dengan menggunakan konsep R\&D Borg and Gall melalui 7 tahap, yaitu: tahap penelitian dan pengumpulan informasi, tahap perencanaan, tahap pengembangan, tahap ujicoba awal, tahap perbaikan draft, tahap ujicoba lapangan dan tahap revisi produk. Pada penelitian ini tidak sampai pada melihat keefektifan $e$-Worksheets dan hanya melihat kelayakan $e$-Worksheets serta respon mahasiswa.

\section{Tahap Pertama}

Pada tahap penelitian dan pengumpulan informasi sebagai tahap awal dari pengembangan $e$ Worksheets ini terdiri dari studi literatur terkait bahan ajar yang ada sebelumnya dan analisis kemampuan abad 21 yang dimiliki mahasiswa sesuai tuntutan kurikulum. Dari hasil kajian literatur ditemukan bahwa belum tersedianya bahan ajar $e$-Worksheet ini, apalagi yang tersedia dalam bentuk elektronik dimana bahan ajar berbentuk elektronik ini memudahkan mahasiswa dalam segi akses dimanapun dan kapanpun. Selain itu, melalui bahan ajar e-Worksheets ini mahasiswa dapat meningkatkan salah satu kemampuan abad 21 yaitu ICT literacy dimana sesuai dengan tuntutan kurikulum program studi yang menghendaki mahasiswa lulusan dapat terfasilitasi dengan sejumlah kompetensi yang memungkinkan untuk dapat survive dalam dinamisnya perkembangan zaman agar menjadi manusia yang mampu beradaptasi dan sukses secara karir. Kecakapan penggunaan teknologi merupakan prasyarat penting untuk pemanfaatan teknologi yang efektif sebagai alat pembelajaran (Davies et al., 2008).

\section{Tahap Kedua}

Tahap kedua yaitu tahap perencanaan yang terdiri dari analisis kurikulum pendidikan matematika; komponen yang harus dikuasai mahasiswa terkait ICT literacy; materi perkuliahan dan penyusunan 
RPS. Penelitian ini dilaksanakan pada mata kuliah Pengantar Teknologi Informasi di Program Studi Pendidikan Matematika. Pengembangan $e$-Worksheets ini mencakup bahan kajian antara lain, Definisi TIK; Peran TIK dalam Pendidikan; Literasi teknologi dan big data; Revolusi Industri 4.0 dan atributnya; potensi pengembangan pendidikan dengan memanfaatkan TIK di era revolusi industri 4.0; penggunaan teknologi yang menunjang proses pembelajaran matematika sekolah. Sedangkan komponen ICT literacy yang harus dikuasai mahasiswa yang terdapat pada $e$-Worksheets ini adalah kemampuan mengakses, mengelola, mengintegrasikan, mengevaluasi dan menciptakan informasi. Sebelum menyusun $e$-Worksheets terlebih dahulu menyusun Rencana Pembelajaran Semester (RPS) berdasarkan kurikulum program studi.

\section{Tahap Ketiga}

Tahap ketiga, yaitu pengembangan produk awal $e$-Worksheets. Pada tahap ini dilakukan persiapan peta konsep, draft 1 e-Worksheeets yang menggunakan ICT literacy, draft uji keterpahaman ide pokok dan uji kualitas $e$-Worksheets. Komponen yang ada pada $e$-Worksheets ini terdiri dari: judul; petunjuk belajar; kompetensi dasar; informasi pendukung; tugas; penilaian. Pada Tabel 5. Berikut akan ditampilkan cuplikan komponen tampilan $e$-Worksheets yang dikembangkan:

Tabel 5. Cuplikan Tampilan Komponen e-Worksheets yang dikembangkan

\begin{tabular}{|c|c|c|}
\hline No & Komponen & Tampilan \\
\hline 1 & Judul & $\begin{array}{l}\text { JUDUL: DEFINISI TEKNOLOGI INFORMASI SERTA PERANANNYA } \\
\text { DALAM PENDIDIKAN }\end{array}$ \\
\hline 2 & $\begin{array}{l}\text { Petunjuk } \\
\text { Belajar }\end{array}$ & $\begin{array}{l}\text { Untuk bisa mengikuti perkuliahan dengan maksimal, mahasiswa diharapkan dapat } \\
\text { mengikuti instruksi-instruksi berikut ini: } \\
\text { a. Mengisi presensi mingguan pada link httpi//bit.do/Absensi.PT setiap hari } \\
\text { selasa dari rentang waktu pukul } 15.30-17.10 \text { WIB. Pengisian presensi di luar } \\
\text { waktu tersebut link presensi ditutup. } \\
\text { b. Baca dan pahami dengan baik uraian materi yang disajikan serta ikuti setiap } \\
\text { instruksi yang diberikan pada tiap LKM. } \\
\text { c. Tontonlah video terkait tema perkuliahan tiap minggunya yang bisa diakses } \\
\text { pada link https://bit.ly/30liglZ } \\
\text { d. Mengumpulkan tugas-tugas yang terdapat pada LKM melalui googleclassroom } \\
\text { dengan kode kelas: atgeimc tepat waktu dengan deadline seminggu setelah } \\
\text { tugas diberikan. } \\
\text { e. Perkuliahan tatap muka via daring tiap minggunya dengan menggunakan zoom } \\
\text { dapat diakses melalui: } \\
\text { f Meeting id: } 7731213779 \\
\text { f. Membaca dan mebki2 } \\
\text { dikomunikasikan pada WAG kelas PTI mingguan terkait perkuliahan yang }\end{array}$ \\
\hline 3 & $\begin{array}{l}\text { Kompetensi } \\
\text { Dasar }\end{array}$ & $\begin{array}{l}\text { (-) KOMPETENSI DASAR } \\
\text { Mahasiswa mampu memahami definisi teknologi informasi, tujuan teknologi informasi, } \\
\text { prinsip teknologi informasi, fungsi teknologi informasi, penggunaan internet di Indonesia, } \\
\text { keuntungan penerapan teknologi informasi serta penerpannya dalam pendidikan. }\end{array}$ \\
\hline 4 & $\begin{array}{l}\text { Informasi } \\
\text { Pendukung }\end{array}$ & $\begin{array}{l}\text { INFORMASI PENDUKUNG } \\
\text { Definisi Teknologi Informasi } \\
\text { - Menurut Haag dan Keen (1999), Teknologi Informasi adalah seperangkat alat yang } \\
\text { membantu manusia bekerja dengan informasi dan melakukan tugas-tugas yang } \\
\text { berhubungan dengan pemrosesan informasi } \\
\text { - Menurut O'Brien (2005), Teknologi informasi merupakan hardware, software, } \\
\text { telekomunikasi, manajemen data base, dan teknologi pemrosesan informasi lainnya } \\
\text { yang digunakan dalam sistem informasi berbasis komputer. }\end{array}$ \\
\hline
\end{tabular}




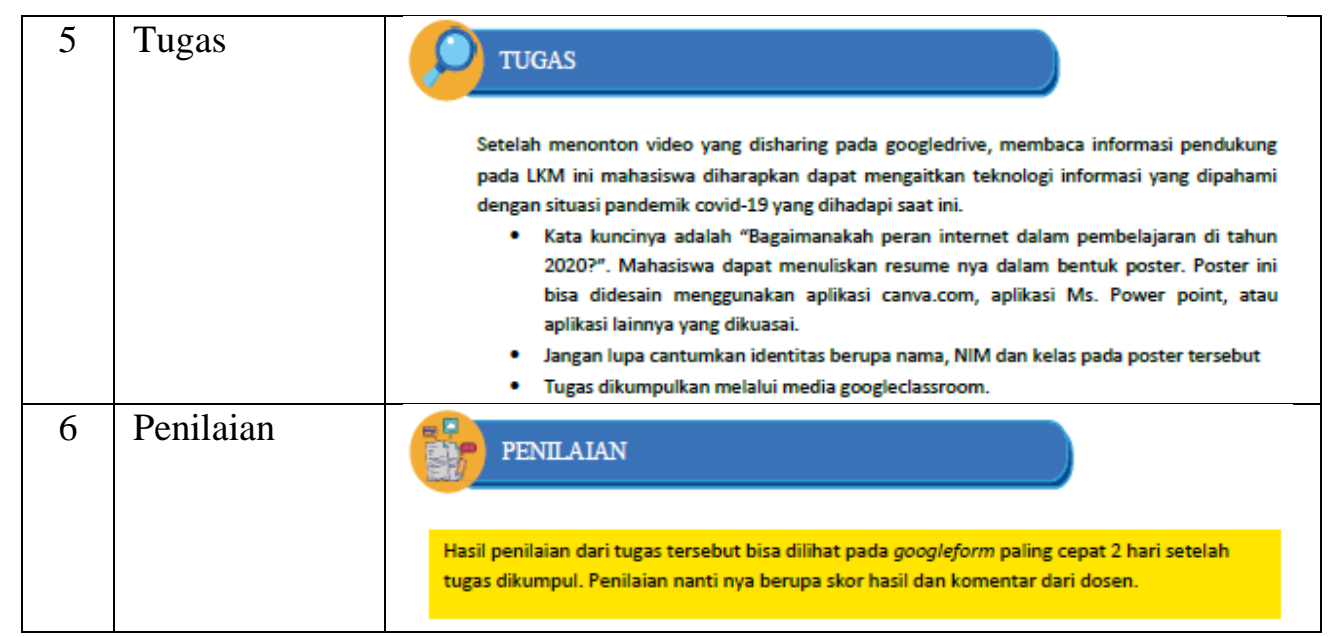

\section{Tahap Keempat}

Tahap keempat, yaitu uji coba lapangan tahap awal. Setelah dirancang, e-Worksheets ini harus divalidasi terlebih dahulu. Tujuan validasi adalah untuk mendapatkan validasi kesesuaian perangkat pembelajaran dengan kebutuhan sehingga sesuai dan layak digunakan dalam pembelajaran (Funa, 2019). Uji coba lapangan tahap awal ini dalam bentuk uji validitas bahan ajar. Dalam hal ini dilakukan dalam skala terbatas untuk uji kualitas $e$-Worksheets kepada 4 orang dosen ahli dan uji keterpahaman ide pokok kepada 30 orang mahasiswa. Penilaian terhadap kualitas $e$-Worksheets yang dikembangkan terdiri dari 18 aspek penilaian yang meliputi kesesuaian antara uraian materi dengan kompetensi dasar, kesesuaian antara pemaparan dan penulisan konten, kesesuaian kegiatan mahasiswa dengan pencapaian ICT literacy. Hasil penelitiannya dapat dilihat pada Tabel 6.

Table 6. Data Hasil Hasil Uji Kualitas e-Worksheetss oleh Dosen

\begin{tabular}{|l|l|c|}
\hline No & Aspek Penilaian & Persentase (\%) \\
\hline A. & Kesesuaian uraian materi dengan kompetensi dasar \\
\hline 1 & Kesesuaian antara kompetensi dasar dan indikator atau tujuan & 87.50 \\
\hline 2 & Kesesuaian setiap indikator dengan uraian aktivitas dan konten & 87.50 \\
\hline 3 & Kesesuaian kompetensi dasar dengan keluasan dan kedalaman konten & 87.50 \\
\hline \multicolumn{2}{|l|}{ Rata-rata } & $\mathbf{8 7 . 5 0}$ \\
\hline B. Kesesuaian antara pemaparan dan penulisan konten & 87.50 \\
\hline 4 & $\begin{array}{l}\text { Kesesuaian materi dengan kemutakhiran ilmu dan teknologi yang } \\
\text { berkembang }\end{array}$ & 81.25 \\
\hline 5 & Struktur dan organisasi material disusun secara logis dan koheren & 75.00 \\
\hline 6 & Gaya pemaparan konten dan aktivitas menarik untuk dibaca & 75.00 \\
\hline 7 & Bahasa tulisan yang digunakan mudah dipahami dan komunikatif. & 75.00 \\
\hline 8 & $\begin{array}{l}\text { Istilah-istilah asing terkait teknologi sudah cukup dikenal oleh target } \\
\text { audiennya. }\end{array}$ & 75.00 \\
\hline 9 & $\begin{array}{l}\text { Pengembangan e-Worksheets menggunakan istilah, simbol dan ikon } \\
\text { yang konsisten }\end{array}$ & $\mathbf{7 8 . 1 2}$ \\
\hline \multicolumn{2}{|c|}{ Rata-rata } \\
\hline C. $\quad$ Kesesuaian kegiatan mahasiswa dengan pencapaian ICT Literacy. \\
\hline 10 & $\begin{array}{l}\text { Uraian materi pada tiap e-Worksheets meningkatkan keterampilan } \\
\text { kognitif dan keterampilan teknis terkait teknologi dan informasi. }\end{array}$ & 81.25 \\
\hline 11 & $\begin{array}{l}\text { Uraian aktivitas pada e-Worksheets mendorong mahasiswa untuk } \\
\text { terampil mengakses informasi terkait teknologi }\end{array}$ & 87.50 \\
\hline
\end{tabular}




\begin{tabular}{|c|l|c|}
\hline 12 & $\begin{array}{l}\text { Uraian aktivitas pada e-Worksheets mendorong mahasiswa untuk } \\
\text { terampil mengelola informasi terkait teknologi }\end{array}$ & 87.50 \\
\hline 13 & $\begin{array}{l}\text { Uraian aktivitas pada e-Worksheets mendorong mahasiswa untuk } \\
\text { terampil mengintegrasikan informasi terkait teknologi }\end{array}$ & 87.50 \\
\hline 14 & $\begin{array}{l}\text { Uraian aktivitas pada e-Worksheets mendorong mahasiswa untuk } \\
\text { terampil mengevaluasi informasi terkait teknologi }\end{array}$ & 81.25 \\
\hline 15 & $\begin{array}{l}\text { Uraian aktivitas pada e-Worksheets mendorong mahasiswa untuk } \\
\text { terampil menciptakan informasi terkait teknologi }\end{array}$ & 87.50 \\
\hline 16 & Aktivitas belajar dan evaluasi sesuai dengan indikator/tujuan & 87.50 \\
\hline 17 & $\begin{array}{l}\text { Tugas yang terdapat pada e-Worksheets sesuai dengan pokok } \\
\text { bahasannya }\end{array}$ & 87.50 \\
\hline 18 & $\begin{array}{l}\text { Penyajian materi yang ada pada e-Worksheets mendorong mahasiswa } \\
\text { untuk mencari informasi yang lebih lanjut }\end{array}$ & 87.50 \\
\hline \multicolumn{3}{|r|}{ Rata-rata } \\
\hline
\end{tabular}

Tabel 6 menunjukkan persentase penilaian kualitas e-Worksheets pada masing-masing aspek penilaian dan masing-masing komponen penilaian. Penilaian tertinggi terdapat pada komponen kesesuaian materi dengan kompetensi dasar yaitu pada persentase $87.50 \%$ dengan kategori sangat sesuai. Sedangkan komponen dengan persentase terendah yaitu kesesuaian antara pemaparan dan penulisan konten dengan persentase $78.12 \%$ pada kategori sesuai. Rendahnya persentasi pada komponen ini terlihat pada aspek gaya bahasa, penggunaan istilah yang belum familiar. Solusi nya disini dengan menanbahkan catatan kaki untuk istilah-istilah tersebut dan memperbaiki gaya bahasa lebih komunikatif. Solusi ini didapatkan dari beberapa saran dan komentar dari dosen yang menvalidasi. Berdasarkan data pada Tabel 6, rata-rata penilaian kualitas e-Worksheet yang dikembangkan mencapai $83,91 \%$ dengan kriteria sangat sesuai. Adapun beberapa aspek yang masih belum maksimal hendaknya diperbaiki untuk hasil yang lebih baik.

Tahap uji coba lapangan tahap awal selanjutnya didapatkan juga data dari uji keterpahaman ide pokok wacana dan kalimat pendukung utama oleh mahasiswa yang dikelompokkan berdasarkan kelompok pokok bahasan diantaranya: Definisi TIK; Peran TIK dalam Pendidikan; Literasi teknologi dan big data; Revolusi Industri 4.0 dan atributnya; potensi pengembangan pendidikan dengan memanfaatkan TIK di era revolusi industri 4.0; penggunaan teknologi yang menunjang proses pembelajaran matematika sekolah. Dalam e-Worksheets ini terdapat 13 wacana. Hasil penelitiannya dapat dilihat dari Tabel 7 berikut:

Tabel 7. Hasil Uji keterpahaman Ide Pokok Wacana

\begin{tabular}{|c|l|c|}
\hline Wacana & \multicolumn{1}{|c|}{ Pokok bahasan } & Persentase (\%) \\
\hline 1 & Definisi teknologi informasi serta peranannya dalam pendidikan & 79.2 \\
\hline 2 & Literasi teknologi & 75.8 \\
\hline 3 & Big Data & 75.8 \\
\hline 4 & Revolusi Industri 4.0 serta dampaknya dalam pendidikan & 77.5 \\
\hline 5 & Pembelajaran Jarak Jauh & 67.5 \\
\hline 6 & Pengenalan Macromedia Flash & 60.0 \\
\hline 7 & Pengenalan Videoscribe & 67.5 \\
\hline 8 & Pengenalan Geogebra & 66.7 \\
\hline
\end{tabular}




\begin{tabular}{|c|l|c|}
\hline 9 & $\begin{array}{l}\text { Mengenal Google Docs, Google drive, Google form, Google } \\
\text { Spreadsheet, Google Slides }\end{array}$ & 71.6 \\
\hline 10 & Pengenalam Prezi & 66.7 \\
\hline 11 & Penggunaan Ms. Powerpoint dan Ms.Excel. & 67.5 \\
\hline 12 & Pengenalan Edmodo dan LMS & 60.8 \\
\hline 13 & Pengenalan Web dan Blog & 62.5 \\
\hline \multicolumn{2}{|l}{ Rata-rata } & $\mathbf{6 9 . 2}$ \\
\hline
\end{tabular}

Tabel 7 menunjukkan persentase keterpahaman ide pokok wacana. Tingkat keterbacaan ide pokok tertinggi terdapat pada wacana 1 dan 4 pada pokok bahasan definisi teknologi informasi serta peranannya dalam pendidikan dan wacana revolusi industri 4.0 serta dampaknya dalam pendidikan dengan persentase masing-masing $79.2 \%$ dan $77.5 \%$ pada kategori keterbacaan tinggi. Sedangkan tingkat keterbacaan terendah terdapat pada wacana 6 pada pokok bahasan pengenalan macromedia flash dengan persentase 60,0 \% dengan kategori keterbacaan sedang. Perlunya memperbaiki kalimat atau kata-kata yang dianggap sulit oleh siswa untuk wacana 6 agar mudah dimengerti oleh siswa. Secara keseluruhan, rata-rata keterpahaman ide pokok untuk 13 wacana tersebut mencapai 69,2\% pada kategori tinggi.

Berdasarkan uji kualitas dan uji keterpahaman ide pokok terhadap e-Worksheets yang telah dikembangkan dapat diperoleh katagori kelayakan e-Worksheets tersebut dari hasil rata-rata persentase keduanya. Hasil data kuantitatif uji kualitas dan uji keterbacaan $e$-Worksheets didapatkan persentase kelayakan sebesar $76.56 \%$ pada kategori layak. Hasil dari uji kelayakan bahan ajar ini dilanjutkan ke tahap selanjutnya.

\section{Tahap Kelima}

Tahap kelima dari pengembangan ini adalah revisi terhadap produk utama yaitu melakukan perbaikan terhadap produk awal draft $1 e$-Worksheets yang dihasilkan berdasarkan hasil ujicoba awal. Perbaikan ini dilakukan setelah mendapat masukan dari uji kualitas dan uji keterpahaman ide pokok $e$-Worksheets sehingga diperoleh draft 2 yang siap diujicoba lebih luas.

\section{Tahap Keenam}

Tahap keenam yaitu ujicoba lapangan utama pada mahasiswa tahun pertama program studi pendidikan matematika dengan melakukan pembelajaran menggunakan e-Worksheets berorientasi ICT literacy. Setelah $e$-Worksheets ini digunakan maka disebarkan angket respon mahasiswa terkait penggunaan $e$-Worksheets yang disajikan yang dikelompokkan ke dalam 4 komponen yaitu komponen pemahaman ICT literacy; komponen penyajian e-Worksheets; komponen motivasi belajar mahasiswa; komponen penulisan dan tata bahasa. Setelah melakukan uji coba lapangan dilanjut dengan tahapan ketujuh yaitu revisi produk, dimana data hasil angket respon mahasiswa diolah dan direvisi berdasarkan hasil respon mahasiswa. Berikut ditampilkan hasil respon mahasiswa pada Tabel 8 . 
Tabel 8. Hasil Respon Mahasiswa terkait penggunaan e-Worksheets berorientasi ICT literacy yang dikembangkan

\begin{tabular}{|c|c|c|}
\hline No & Pernyataan & Persentase (\%) \\
\hline A. & \multicolumn{2}{|l|}{ Komponen pemahaman ICT literacy } \\
\hline 1 & \multicolumn{2}{|c|}{\begin{tabular}{l|l}
$e$-Worksheets ini dapat melatih kemampuan ICT literacy saya & 82.5 \\
\end{tabular}} \\
\hline 2 & $\begin{array}{l}\text { e-Worksheets ini dapat melatih kemampuan dasar saya dalam } \\
\text { penggunaan teknologi yang menunjang perkuliahan }\end{array}$ & 82.5 \\
\hline 3 & e-Worksheets ini memberikan wawasan bagi saya terkait Big Data & 82.5 \\
\hline 4 & $\begin{array}{l}\text { e-Worksheets ini memberikan wawasan bagi saya terkait Literasi } \\
\text { Teknologi }\end{array}$ & 80.0 \\
\hline 5 & $\begin{array}{l}e \text {-Worksheets ini memberikan wawasan bagi saya terkait Revolusi } \\
\text { Industri } 4.0 \text { dan peranannya dalam dunia pendidikan }\end{array}$ & 85.0 \\
\hline 6 & $\begin{array}{l}\text { e-Worksheets ini membuat saya sadar akan pentingnya skills } \\
\text { penggunaan teknologi dalam kehidupan }\end{array}$ & 82.5 \\
\hline & Rata-rata & 82.5 \\
\hline B. & \multicolumn{2}{|l|}{ Komponen Penyajian e-Worksheets } \\
\hline 7 & Tampilan $e$-Worksheets ini sangat menarik & 85.0 \\
\hline 8 & $\begin{array}{l}\text { Tiap komponen yang ada dalam } e \text {-Worksheets ini disusun dengan } \\
\text { sistematis sehingga mudah untuk dipahami. }\end{array}$ & 84.2 \\
\hline 9 & $\begin{array}{l}\text { Layout e-Worksheets ini memudahkan saya dalam mengerjakan } \\
\text { setiap kegiatan }\end{array}$ & 82.5 \\
\hline 10 & $\begin{array}{l}\text { Komposisi penggunaan gambar dan tulisan yang ada dalam } e \text { - } \\
\text { Worksheets ini sesuai dengan keperluan }\end{array}$ & 82.5 \\
\hline & Rata-rata & 83.6 \\
\hline C. & \multicolumn{2}{|l|}{ Komponen Motivasi Belajar Mahasiswa. } \\
\hline 11 & $\begin{array}{l}\text { e-Worksheets ini dapat meningkatkan pemahaman saya terhadap } \\
\text { materi perkuliahan yang diberikan }\end{array}$ & 87.5 \\
\hline 12 & $\begin{array}{l}\text { Penggunaan e-Worksheets ini membuat perkuliahan menjadi } \\
\text { menyenangkan }\end{array}$ & 87.5 \\
\hline 13 & $e$-Worksheets ini dapat menambah keinginan untuk belajar & 90.0 \\
\hline 14 & $e$-Worksheets ini dapat memperbaiki cara belajar saya selama daring & 87.5 \\
\hline 15 & $\begin{array}{l}\text { Tugas-tugas yang terdapat pada } e \text {-Worksheets ini dapat saya kerjakan } \\
\text { dengan baik }\end{array}$ & 85.0 \\
\hline 16 & $\begin{array}{l}\text { e-Worksheets ini sangat membantu perkuliahan secara daring karena } \\
\text { memfasilitas mahasiswa untuk mendapatkan sumber pembelajaran } \\
\text { dengan lebih terarah dan bisa diakses kapanpun dan dimanapun }\end{array}$ & 90.0 \\
\hline & Rata-rata & 87.92 \\
\hline $\mathbf{D}$ & Komponen Penulisan dan Tata Bahasa & \\
\hline 17 & Simbol-simbol yang digunakan mudah terbaca & 79.2 \\
\hline 18 & $\begin{array}{l}\text { Penggunaan kalimat/tata bahasa di dalam } e \text {-Worksheets ini mudah } \\
\text { dipahami }\end{array}$ & 81.6 \\
\hline 19 & $\begin{array}{l}\text { Pada narasi dalam } e \text {-Worksheets ini menggunakan istilah yang saya } \\
\text { ketahui artinya }\end{array}$ & 77.5 \\
\hline 20 & Huruf yang digunakan sederhana dan mudah dibaca & 82.5 \\
\hline & Rata-rata & 80.2 \\
\hline & Rata-rata keseluruhan & 83.6 \\
\hline
\end{tabular}

Berdasarkan data pada Tabel 8 diperoleh persepsi mahasiswa terkait e-Worksheets yang dikembangkan untuk tiap-tiap komponen. Komponen pertama yaitu komponen pemahaman ICT literacy diperoleh persentase persepsi mahasiswa sebesar $82.5 \%$ pada kategori sangat setuju, mahasiswa sepakat bahan ajar ini meningkatkan kemampuan ICT literacy, terampil penggunaan 
teknologi dalam perkuliahan, memberi wawasan terkait literasi teknologi, wawasan terkait big data dan wawsan terkait revolusi industri 4.0. Komponen kedua, yaitu komponen penyajian $e$-Worksheets diperoleh persentase persepsi mahasiswa sebesar $83.6 \%$ pada kategori sangat setuju, hal ini menggambarkan bahwa susunan, layout dan komposisi $e$-Worksheets ini mudah dipahami dan sesuai keperluan mahasiswa. Komponen ketiga, yaitu komponen motivasi belajar mahasiswa diperoleh persentase persepsi mahasiswa sebesar $87.92 \%$ pada kategori sangat setuju, pada komponen ini memperlihatkan kehadiran bahan ajar ini membuat perkuliahan daring lebih menyenangkan, pemahaman materi lebih meningkat, keinginan belajar lebih besar dan memperbaiki cara belajar mahasiswa. Komponen keempat, yaitu komponen penulisan dan tata bahasa $80.2 \%$ pada kategori sangat setuju, dalam hal ini memperlihatkan simbol, kalimat, huruf dan istilah yang digunakan cukup mudah dipahami. Persepsi mahasiswa terkait penggunaan $e$-Worksheets secara keseluruhan diperoleh persentase $83.6 \%$ dengan kategori sangat setuju. Hal ini memperlihatkan bahwa e-Worksheets ini memfasilitasi mahasiswa dalam belajar, dan termotivasi untuk menyelesaikan setiap tugas yang ada pada e-Worksheets berorietasi ICT literacy ini. Jika mahasiswa merasa nyaman dan mampu mengerjakan tugasnya dengan baik, maka kemungkinan besar mahasiswa tersebut akan berprestasi baik diukur dari kinerjanya (Sulisworo, 2015). Motivasi belajar dapat memprediksi keberhasilan belajar.

Dalam dunia pendidikan, kontribusi teknologi informasi (TI) memberi kesempatan bagi peserta didik untuk lebih bertanggung jawab atas pengalaman belajar mereka sendiri (Ezziane, 2007). Karena dalam kenyataannya dunia kerja yang berbasis pengetahuan membutuhkan tenaga kerja terdidik dari individu yang melek Teknologi Informasi dan dapat memanfaatkan kekuatan ICT. Hal ini sejalan dengan tujuan menghadirkan bahan ajar berupa $e$-Worksheets pada perkuliahan pengantar teknologi informasi untuk mahasiswa tahun pertama pada program studi pendidikan matematika. Bahan ajar berupa $e$-Worksheets ini memfasilitasi mahasiswa untuk mendapatkan pengalaman belajar mereka sendiri untuk suskses kedepannya.

\section{Tahap Ketujuh}

Tahap terakhir dari pengembangan bahan ajar berupa $e$-Worksheets ini adalah revisi produk/ revisi draft $2 e$-Worksheets. Tahapan ini dilakukan guna menyempurnakan $e$-Worksheets dengan melengkapi sampul depan, sampul belakang, daftar isi, kata pengantar yang bisa dilihat pada Gambar 2 berikut: 

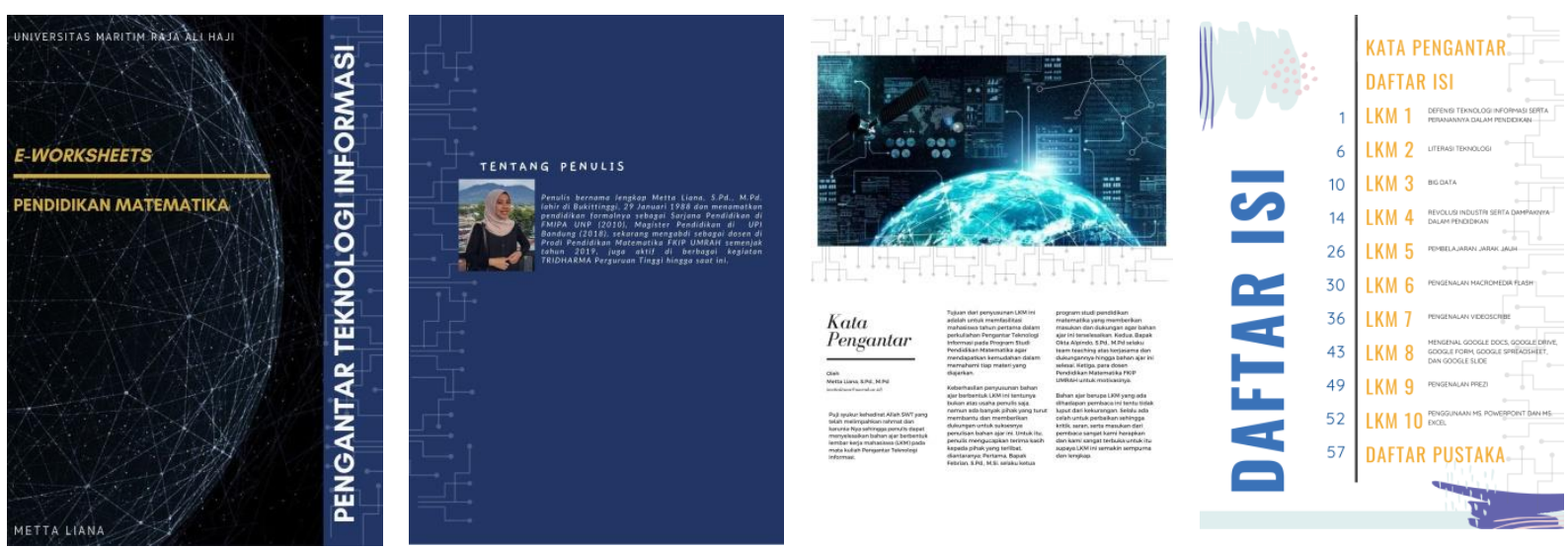

Gambar 2. Tampilan Sampul Depan, Sampul Belakang, Kata Pengantar dan Daftar Isi dari e-Worksheets yang dikembangkan

Selain melengkapi e-Worksheets dengan sampul depan, sampul belakang, kata pengantar dan daftar isi, pada tahap ini dilakukan juga pengecekan secara menyeluruh terhadap penggunaan Ejaan Yang Disempurnakan (EYD) dan ketepatan penyusunan kalimat dalam bahasa Indonesia yang baik dan benar. Sehingga, $e$-Worksheets ini nantinya bisa diujicobakan pada lapangan yang lebih luas.

\section{KESIMPULAN}

Pengembangan bahan ajar berupa $e$-Worksheets pada perkuliahan pengantar teknologi informasi untuk mahasiswa tahun pertama pada program studi pendidikan matematika bertujuan untuk memfasilitasi mahasiswa untuk mendapatkan pengalaman belajar mereka sendiri untuk suskses kedepannya. Di samping itu, hadirnya bahan ajar ini bisa digunakan pada pembelajaran daring maupun luring. Adapun keterbatasan pada penelitian ini, pertama karena teknologi yang terus berkembang, penggunaan bahan ajar ini tiap tahunnya butuh revisi terkait kebaruan teknologi terkini dan isu yang berkembang. Kedua, penelitian pengembangan ini hanya sampai tahap uji kelayakan dan melihat respon siswa terkait pengguaan $e$-Worksheets berorientasi ICT literacy karena keterbatasan waktu. Hendaknya nanti bisa disusun instrumen tes mengukur ICT literacy. Meskipun dengan hasil respon mahasiswa cukup mewakili penilaian terkait $e$-Worksheet, tetapi dengan membandingkan hasil tes ICT literacy dengan respon mahasiswa akan memberikan hasil yang lebih baik untuk penelitian ini.

Akhir kata, tidak ada yang sempurna dari hasil pengembangan sebuah bahan ajar, selalu ada perbaikan kedepannya untuk hasil yang lebih baik. Pengembangan bahan ajar yang baik, selalu mengarahkan peserta didik untuk mendapatkan pengalaman belajarnya sendiri dan menjadikan pendidik sebagai fasilitator dalam pembelajaran. Saran penelitian selanjutnya pada: (1) bagaimana penggunaan $e$-Worksheet berorientasi ICT literacy menggunakan pendekatan/model pembelajaran saintifik ?. (2) Bagaimana ICT literacy mahasiswa yang menggunakan e-Worksheets yang dikembangkan ?. 


\section{UCAPAN TERIMA KASIH}

Puji dan syukur kepada Tuhan Yang Maha Esa atas berkah dan rahma-Nya sehingga penulis dapat menyelesaikan artikel penelitian ini tepat waktu. Pada kesempatan ini, penulis juga mengucapkan terima kasih kepada Aulya Ade Rahmi, ST. yang telah membantu dalam mendesain $e$-Worksheets berorientasi ICT Literacy yang dikembangkan. Lebih lanjut, ucapan terima kasih kepada dosen dan mahasiswa yang telah berpartisipasi dalam penelitian ini.

\section{REFERENSI}

Anderson, R., \& Ainley, J. (2010). Technology and learning: Access in schools around the world. International Encyclopedia of Education, 21-33. https://doi.org/10.1016/B978-0-08-0448947.01714-0

Asrizal, Amran, A., Ananda, A., \& Festiyed. (2019). Effects of science student worksheet of motion in daily life theme in adaptive contextual teaching model on academic achievement of students. Journal of Physics: Conference Series, 1185(1). https://doi.org/10.1088/17426596/1185/1/012093

Australian Council for Educational Research. (2016). A global measure of digital and ICT literacy skills.

Beneova, A., \& Tupa, J. (2017). Requirements for Education and Qualification of People in Industry 4.0. 27th International Conference on Flexible Automation and Intelligent Manufacturing, FAIM2017, 11(June), 2195-2202. https://doi.org/10.1016/j.promfg.2017.07.366

Borg, W. R., \& Gall, M. D. (2003). Educational Research: An Introduction (7th ed.). Retrieved from Allyn \& Bacon

Davies, R. S., Sprague, C. R., \& New, C. M. (2008). Integrating Technology into a Science Classroom An evaluation of inquiry-based technology integration. The Impact of Technology and the Laboratory on K-16 Science Learning Series: Research in Science Education, pp 207237.

Departemen Pendidikan Nasional. (2008). Memilih bahan Ajar. Jakarta: Depdiknas.

Eisenberg, M.B., \& Johnson, D. (2002). Learning and Teaching Information Technology Computer Skills in Context. ERIC Document Reproduction No. ED 465377.

Ezziane, Z. (2007). Information technology literacy: Implications on teaching and learning. Educational Technology and Society, 10(3), 175-191.

Funa, A. A. (2019). Validation of Gamified Instructional Materials in Genetics for Grade 12 STEM Students. International Journal of Sciences: Basic and Applied Research (IJSBAR), 47(July), pp 168-180.

Gaston, P., Station, F., \& Taylor, L. A. (2002). Digital Transformation A Framework for ICT Literacy ICT Literacy Panel.

Hansen, B. J. W. (2003). To Change Perceptions of Technology Programs. Journal of Technology 
Studies, 29, 16-19.

Kagermann, Wahlster, W., \& Helbig, J. (2013). Recommendations for implementing the strategic initiative INDUSTRIE 4.0. Final Report of the Industrie 4.0 WG.

Peck, C., Cuban, L., \& Kirkpatrick, H. (2003). High-tech's high hopes meet student realities. Education Digest, 67(8), 47-54.

Rankin, Earl F \& Culhane, Joseph W. (1969). Comparable Cloze and Multiple-Choice Comprehension Test Scores. J Reading,13, 3

Sinaga, P., Suhandi, A., \& Liliasari. (2014). Improving the ability of writing teaching materials and self-regulation of pre-service physics teachers through representational approach. International Journal of Sciences: Basic and Applied Research, 15(1), 80-94.

Sudjana. (2005). Metode Statistika. Bandung: Transito

Sugiyono. (2011). Metode Penelitian Pendidikan (pendekatan kuantitatif, kualitatif, dan R\&D). Bandung: Alfabeta

Sulisworo, D. (2015). The Effect of Cooperative Learning, Motivation and Information Technology Literacy to Achievement. International Journal of Learning \& Development, (April 2014). https://doi.org/10.5296/ijld.v4i2.4908

Wildemeersch, D., \& Jütte, W. (2018). Editorial : digital the new normal - multiple challenges for the education and learning of adults. European Journal for Research on the Education and Learning of Adults, 8, No 1(April 2017), pp 7-20. https://doi.org/10.3384/rela.2000-7426.relae13 